\title{
Impact of Household Size and Family Composition on Poverty in Rural India
}

\author{
by
}

\author{
J.V. Meenakshi \\ Centre for Development Economics \\ Delhi School of Economics \\ Delhi University \\ Delhi - 110007 \\ India \\ Email: $\underline{\text { meena@cdedse.ernet.in }}$
}

\author{
Ranjan Ray \\ School of Economics \\ University of Tasmania \\ GPO Box 252-85 \\ Hobart Tas 7001 \\ Australia \\ Email: Ranjan.ray@utas.edu.au
}

Written: April 1999

Revised: July 2000

"The work on this paper was partially supported by a grant from the Australian Research Council. We are grateful to Geoffrey Lancaster and Souvik Gupta for research assistance. Helpful comments from Jean Dreze and anonymous referees are gratefully acknowledged. The disclaimer applies. 


\begin{abstract}
This paper utilises micro data on consumption, family composition and land ownership of nearly 70,000 rural Indian households to analyse poverty in rural India. The study, conducted at the disaggregated level of individual States, examines the impact of household size and composition, caste, gender of household head, and size of land ownership on a household's poverty status. The introduction of consumption economies of household size and of adult/child consumption relativities affect the poverty estimates but not the State poverty rankings. Scheduled castes/tribes are more vulnerable to poverty than others. In contrast, female headed households display, in many States, higher poverty only in the presence of size economies and adult/child relativities. However, the latter result is not always true. On this and in several other respects, the study finds sharp differences between the constituent States of the Indian Union.
\end{abstract}

JEL Classification:

C81, D63, I32, J18, o57

Keywords:

Economies of Household Size, Adult Equivalence Scales, Head Count Poverty Rate, Land Deprivation, Female Headed Households, Scheduled Castes and Scheduled Tribes 


\section{Introduction}

The issue of sensitivity of poverty estimates to the treatment of household size has recently attracted considerable attention [Buhmann, et al (1988), Coulter, et al (1992), Lanjouw and Ravallion (1995), Dreze and Srinivasan (1997), Lancaster, et al (1999)]. Much of the interest in these studies has focussed on the impact of allowing economies of household size on the poverty calculations. The results of Lanjouw and Ravallion (1995) on Pakistan data show, for example, that the presence of size economies in consumption is likely to counter the widely held view that larger families tend to be poorer in developing countries. Dreze and Srinivasan (1997) observe on India's National Sample Survey data that "poverty indices for different household types ... are quite sensitive to the level of economies of scale" (p. 217). The empirical literature on developed countries also points to the importance of size economies in welfare comparisons across households. Nelson (1988) found evidence on US data of "existence of significant economies of scale in the consumption of all the included goods, with economies being especially pronounced in the consumption of shelter". Buhmann, et al (1988), using cross country data from the Luxembourg Income Study data base of 10 developed countries, and Coulter, et al (1992), using the UK Family Expenditure Survey data, both found sensitivity of inequality and poverty estimates to the presence of size economies in consumption and, more generally, to the equivalence scale relativities used in the welfare comparisons. In an analysis of Norwegian data, Ringen (1991) found that comparisons of standards of living over time do depend on whether a per equivalent or a per capita measure is used.

Most of the studies, referred to above, assume a common functional form for the equivalence scale, namely, $\mathrm{N}^{\theta}$ where $\mathrm{N}$ is household size, ie. the unweighted number of members in the household. The parameter $\theta$ is, therefore, relied upon to pick up not only the size economies of consumption but, also, the effect of change in household composition 
between adults and children. The latter follows from the non identical consumption needs between adults and children, a fact that is central to the equivalence scale literature. The empirical literature on the sensitivity of poverty calculations to the equivalence scale specification does not, usually, distinguish between the effects of household size and family composition on the estimates. In developed countries, the two effects are likely to be related, since larger families will tend to be younger or, at least, will have more young children. The situation is quite different and more complex in the developing countries, especially in the Indian sub continent, with the prevalence of the joint family system, and with children staying on with their parents to a much later age than in the advanced countries. The absence of any direct role for changes in household composition in the equivalence scale specification, $\mathrm{N}^{\theta}$, raises the issue of robustness of the earlier findings to the explicit recognition of non identical needs between adults and children. Such an investigation based on the unit records from Indian National Sample Survey data constitutes one of the principal motivations of this study. A prima facie case is provided by the results of Lancaster, et al. (1999) who observe, on cross country micro data from a selection of developing and developed countries, that some of the relationships observed earlier between poverty estimates and size economies of consumption are unlikely to be robust in the presence of household compositional variables.

The recent availability of household level micro consumer expenditure survey data by the National Sample Survey Organisation offers exciting opportunities to contribute to the rich literature on poverty and welfare changes in India. In this paper, we exploit the household level information to examine the extent to which poverty comparisons are influenced by (a) demographic factors and (b) alternative poverty lines. We also extend the analysis to include social groups believed to be particularly vulnerable to deprivation: scheduled caste/scheduled tribe and female headed households. The analysis pertains to the 
$50^{\text {th }}$ round of the NSS consumer expenditure survey, carried out in 1993/1994, and is restricted to rural India.

Poverty studies on India have tended to ignore the question of economies of household size in consumption [see, for example, Dreze and Srinivasan (1996), Dubey and Gangopadhyay (1998), Datt and Ravallion (1998)]. Traditional analyses of poverty and welfare are conducted on a per capita basis, wherein households whose per capita incomes fall below a pre specified norm are identified as being poor. This approach ignores the fact that household members cooperate with each other and thereby get more out of their household incomes than would be possible if members operated as individual households. This includes the sharing of several fixed-cost components of a running household: rent for Housing is the most obvious example of this. Further, larger households may be able to take advantage of bulk discounts associated with larger purchases of a given commodity, say, cereals and thereby achieve a greater level of utility than could a smaller household. As already explained, this objection to the use of family size as the expenditure deflator is distinct from the argument that it overlooks the non identical needs between the different members of the household, most notably, between adults and children.

While the importance of incorporating household size and composition in welfare analysis has long been recognised, empirical work on Indian data has been relatively scarce. One exception is the study by Dreze and Srinivasan (1997) who utilise disaggregated data on household size and composition to analyse the economic position of female headed households. They experiment with a variety of adult equivalent scales and economies of household size parameters for rural India. They find that the poverty ranking of different household types is invariant to the choice of adult equivalence scales, but is sensitive to the choice of economies of household size parameters. The Dreze and Srinivasan (1997) study, like Buhmann, et al (1988), does not estimate these parameters but examines the sensitivity of 
the results to the choice of a range of possible values of these parameters. Moreover, in common with most welfare analysis on Indian data, the Dreze and Srinivasan exercise does not allow the size economies and the adult equivalence scales to vary between the different regions in India. This is contrary to the evidence presented in Meenakshi and Ray (1999) which confirms that the impact of household size and composition on expenditure pattern varies sharply between the different States in India.

The present study extends the empirical literature on poverty in India in principally the following respects:

(i) We explicitly introduce in the equivalence scale functional form both household size and household composition variables, namely, the number of adults and children in the household. This allows us to test, simultaneously, for the presence of economies of household size and of non identical consumption needs between adults and children.

(ii) We exploit the rich household level information contained in the unit records, made available recently by the National Sample Survey Organisation, to estimate simultaneously the size economies and adult equivalence scale parameters for each of the constituent States of the Indian Union. The fact that the present study estimates these parameters rather than experiment with alternative starting values constitutes a significant departure from the previous literature.

(iii) The issue of sensitivity of poverty calculations is examined not only with respect to the demographic parameters, as discussed above, but also with respect to the poverty line expenditure used in the calculations. ${ }^{1} \mathrm{We}$ investigate the sensitivity of the poverty rankings of the Indian States to alternative poverty lines. These differ from each other not only because of the different parametric values of the adult equivalence scale, but also because of differences in the way the poverty level expenditure is defined. In the latter context, we compare the State poverty rankings based on the nutritionally determined OPL (official poverty line) with that based on a priori specified cut offs for budget share of Cereals. The OPL in India is anchored in the cost of a normative minimum food basket that ensures 2400 calories per capita per day in rural areas, and is updated using State specific cost of living indices as recommended by Minhas, et al (1990). An alternative way of specifying the poverty line is the 'Food Ratio' method that has the appeal of simplicity in terms of its conceptual basis. It is based on the Engel observation that the proportion of income spent on necessities tends to fall as incomes rise. A threshold distinguishing the poor from the non poor can thus be framed in terms of the expenditure level at which a specified proportion spent on necessities is just reached on average. This approach ha s been employed by Statistics

${ }^{1}$ See Nolan and Whelan (1996, Ch 2) for a comprehensive review of the alternative poverty lines used in the literature. 
Canada to produce low income cut offs and has, also, been used quite widely in developing countries [see Rao (1981)]. Notwithstanding its considerable appeal because of its simplicity and modest information requirements, the 'Food ratio' method is not without its limitations [see, for example, Chaudhuri and Ravallion (1994)]. In the present study, the 'Food Ratio' method is implemented using a priori specified threshold share of Cereals in the household budget: high cereal share is indicative of an impoverished household, while a low cereal share indicates that the household is food secure. This still leaves open the question of what constitutes the cut off between 'high' and 'low' cereal shares. There is no straight forward answer: we try a pair of cut offs and examine whether the results are robust.

(iv) In an attempt to identify households that are particularly vulnerable to poverty, we pay special attention to two groups: (a) female headed households (FHH), and (b) those belonging to scheduled castes and scheduled tribes (SC/ST). There is now considerable evidence to suggest that FHH are poorer than others (see, for example, Buvinic and Gupta (1997)'s evidence on Chile), though Dreze and Srinivasan (1997) observe that this result, in the case of widowed households, is sensitive to the presence of size economies of consumption. The vulnerability of SC/ST households to acute poverty is recognised in the arrangements for job reservations made for these groups in India. However, there exists little evidence on the magnitude of poverty experienced by the backward classes in India. The present study will attempt to throw light on this issue.

(v) This study widens the scope of the poverty analysis by presenting evidence on relative land deprivation in India's rural areas based on a measure of landlessness proposed in this paper. Land ownership is an important source of income in the rural areas. Though it is misleading to identify landlessness with poverty, it is interesting to examine the extent to which the picture on land deprivation in the different States in India resembles that on poverty.

The paper extends the recent study of Dreze and Srinivasan (1997) (D\&S) on poverty

in rural India in several respects.

(a) While D\&S use the NSS data for 1986/87, the present study is based on the more recent NSS data for 1993/94.

(b) Unlike D\&S, we incorporate differences in needs and preferences between the various States of the Indian Union. A key feature of our results is that the nature of sensitivity of the poverty rates of female headed households with respect to economies of household size, that D\&S observe, is not robust between the different States and regions. It is, therefore, somewhat misleading to present the picture only at the all India level.

(c) While D\&S do not explicitly look at the plight of SC/ST households, a separate investigation of the poverty rates of such households is a special feature of this study. The present exercise is one of the first attempts at comparing the poverty rates of the socially disadvantaged groups, namely, the female headed and the SC/ST households, with one another and with the rest of the population. 
(d) While D\&S concentrate exclusively on the size economies parameter in picking up demographic effects, the present exercise on sensitivity of the poverty estimates to the equivalence scale is undertaken with respect to the simultaneous variation of the size economies and the adult/child relativities parameters. In other words, unlike D\&S, we distinguish between the two, and allow them separate roles in determining the equivalence scales.

(e) Most crucially, while D\&S investigate sensitivity with respect to alternative assumed values of size economies and, hence, of the equivalence scale, we estimate the scale from the available expenditure and demographic information. Consequently, while the alternative scale values considered in D\&S are necessarily ad hoc, ours are not, since these correspond to estimated functional parameters. Incidentally, while the welfare interpretation of equivalence scales estimated on conventional budget data is problematic [see Pollak and Wales (1979)], the present study in common with others [Lanjouw and Ravallion (1995), Nelson (1988)] does not require any deep welfare significance to be attached to the scale estimates. Besides these studies, we follow Pollak and Wales [1992, Ch. 3] in using the estimated equivalence scales as expenditure deflators to incorporate changes in household size and composition.

To focus our minds more concretely on the principal features of this study, let us list

below the substantive questions that we seek to answer.

(i) Do there exist significant size economies of consumption even in the presence of non identical consumption needs between adults and children? Do the estimates of economies of scale of household size, and of adult equivalence scales, vary across the States of the Indian Union?

(ii) Do the poverty estimates and the poverty rankings of the different States vary between the conventional treatment of household size as the unweighted sum of individual members, and one where we allow both size economies of scale and non identical consumption needs between adults and children?

(iii) Are the poverty estimates and the poverty rankings of the Sates sensitive to the poverty line, namely, between the nutritionally based, official poverty line (OPL) and the, cereal share based, behaviourally determined poverty line (BD)? How do these estimates and rankings compare with those based on an index of la nd deprivation (LD)?

(iv) Do the female headed households $(\mathrm{FHH})$ and those belonging to the backward classes (SC/ST) face higher poverty rates than the rest of the population?

These are clearly questions of considerable policy concern. The Federal government in India has adopted poverty alleviation as an important criterion in the disbursement of Central assistance to the constituent States. Moreover, as attention has shifted in the poverty 
literature to the targeting of anti poverty strategies at groups that are considered to be particularly vulnerable to poverty, the answers to (iv) hold considerable policy interest.

The remainder of this paper is as follows. Section 2 presents the methodology used in this study. The data is described, and its principal features are discussed in Section 3. The results are presented and discussed in Section 4. The main conclusions are summarised in Section 5 .

\section{Methodology}

\subsection{Demand Systems, Size Economies and Equivalence Scales}

The estimates of economies of household size and of adult equivalence scales were obtained by estimating the following Engel curves expressed in budget share terms, $\mathrm{w}_{\mathrm{i}}$ :

$$
\begin{array}{r}
\mathrm{w}_{\mathrm{i}}=\left(\alpha_{\mathrm{i}}+\delta_{\mathrm{i} 1} \mathrm{D}_{1}+\delta_{\mathrm{i} 2} \mathrm{D}_{2}+\delta_{\mathrm{i} 3} \mathrm{~L}\right)+\beta_{\mathrm{i}}[\log (\mathrm{Y} / \mathrm{N})]+\gamma_{\mathrm{i}}[\log (\mathrm{Y} / \mathrm{N})]^{2}+\mathrm{u}_{\mathrm{i}} \quad(1) \\
\mathrm{i}=1, \ldots, \mathrm{n}
\end{array}
$$

where $\mathrm{Y}$ is aggregate household expenditure, $\mathrm{N}=\left(\mathrm{n}_{\mathrm{a}}+\rho \mathrm{n}_{\mathrm{c}}\right)^{\theta}$ is the economies of scale and equivalence scale adjusted measure of household size. $\mathrm{n}, \mathrm{n}_{\mathrm{c}}$ denote the number of adults, children, respectively, in the household and $\theta, \rho$ are the demographic parameters. $D_{1}, D_{2}$ are dummy variables corresponding to households belonging to SCST and FHH respectively, L is the size of landholdings owned by the household, and $\mathrm{u}$ is the stochastic error term. The introduction of dummy variables in this manner is analogous to the "translation" procedure of Pollak and Wales [1992, Ch 3] which allows a subset of parameters in the original demand system $\left(\alpha_{\mathrm{i}}\right.$ in this case) to depend on demographic variables $\left(\mathrm{D}_{1}, \mathrm{D}_{2}, \mathrm{~L}\right.$ in this case). $\delta_{\mathrm{i} 1}, \delta_{\mathrm{i} 2}$, $\delta_{\mathrm{i} 3}$ represent, therefore, the impact of social backwardness, female headship and size of landholdings on the budget share of item i, after controlling for the other variables. Owing to the presence of non linearity and cross equation restrictions because of the parameters $\rho, \theta$ 
appearing in each equation, (1) was estimated as a system of equations using non linear FIML and the SHAZAM (version 8.0) computer package. Note that when $\theta=\rho=1, \mathrm{~N}$ specialises to the conventional treatment of household size as simply the number of members in the household. All the households within a State are assumed to face the same prices in a given time period. The quadratic coefficients, $\gamma_{i}$, allow the possibility of items changing from necessities to luxuries or vice versa as we move across the expenditure spectrum.

\subsection{Alternative Poverty Lines}

Using the estimates of $\theta, \rho$, for each State, the alternative poverty lines can be obtained as follows:

(i) The State specific poverty lines, taking account of size economies and equivalence scale relativities, were obtained by multiplying the per capita OPL figures reported for each State in Dubey and Gangopadhyay $\left(1998\right.$, Table S2.2A) by $\left(\bar{n}_{a}+\rho \bar{n}_{c}\right)^{1-\theta}$, where $\overline{\mathrm{n}}_{\mathrm{a}}$ is the average number of adults, and $\overline{\mathrm{n}}_{\mathrm{c}}$ is the average number of children in the State sample. ${ }^{2}$ Within the framework set by the official poverty line, we obtain 4 different versions of this line, namely, (a) OPL1 when $\rho, \theta$ take on their estimated values, (b) OPL2 when $\theta=1$, and $\rho$ takes on the estimated value, assuming absence of size economies, (c) OPL3 in the per capita case ${ }^{3}$, ie. $\theta=\rho=1$ (assumed), and (d) OPL4 when $\rho=1$, and $\theta$ takes on its estimated value assuming identical weights for adults and children. ${ }^{4}$

(ii) The alternative poverty line, considered here, fixes it at the level of expenditure at which a single adult household spends a pre-specified share, $\hat{\mathrm{w}}_{\mathrm{c}}$, of the household budget on Cereals and Cereal substitutes. The Cereal share based poverty line used here is based on the Engel idea of an inverse link between the budget share of necessities and household welfare. Consequently, households which are observed to spend a greater than the pre-specified share, $\hat{\mathrm{w}}_{\mathrm{c}}$, on Cereals and Cereal substitutes are deemed to be "poor". From the parameter estimates $\left(\hat{\alpha}_{c}, \hat{\beta}_{c}\right)$ of the Cereals equation, and considering only the linear version of eqn. (1) for simplicity (ie. assuming

\footnotetext{
${ }^{2}$ See Dreze and Srinivasan (1997, p 225) for an explanation of this particular form of poverty line adjustment, extended here to allow for $\rho \neq 1$. As they point out, "this convention implies that a household of average size is counted as 'poor' if and only if it has a per capita expenditure below [OPL] irrespective of the value" of $\theta$. ${ }^{3}$ OPL 3 coincides with the OPL figures reported by Dubey and Gangopadhyay (1998).

${ }^{4}$ OPL4 is the case considered by Buhmann, et. al. (1988), Lanjouw and Ravallion (1995), Dreze and Srinivasan (1997).
} 
$\left.\gamma_{c}=0\right)$, the behaviourally determined poverty line (BDPL) for a single adult household is given by:

$$
\mathrm{BDPL}=\exp \cdot\left[\frac{\hat{\mathrm{w}}_{\mathrm{c}}-\hat{\alpha}_{\mathrm{c}}}{\hat{\beta}_{\mathrm{c}}}\right]
$$

Note, incidentally, that the numerically small $\gamma_{c}$ estimates, reported later, make the approximation implicit in (2), a realistic one. The poverty lines for the different households, varying in size and composition, can then be constructed from BDPL using the same adjustment as described above for OPL. In the calculations reported below, we use only the most general equivalence scale specification ie. use $\theta, \rho$ at their estimated values for each State as with OPL1. We investigate the sensitivity of the poverty estimates to the Cereal share cut off by reporting the calculations at two threshold values $\left(\hat{\mathrm{w}}_{\mathrm{c}}=0.35,0.4\right)$. These cut off points were chosen after preliminary investigation of the data.

(iii) In addition to the poverty estimates, we examine the extent of landlessnes s or land deprivation in the rural areas of India by using the index, LD, to denote the percentage of households with land holdings per equivalent adult that is less than $50 \%$ of the sample mean of per equivalent land holdings ${ }^{5}$.

\section{Data and Its Principal Features}

The data base for this study is provided by the unit record data on consumer expenditure in the rural areas collected for each of the States in India in the $50^{\text {th }}$ round of the National Sample Survey (1993/94). The following 11 commodity expenditure classification was used in estimating the economies of household size and the adult equivalence scale parameters: Cereals and Cereal Substitutes; Pulses and Pulse Products; Milk and Milk Products; Meat, Eggs and Fish; Edible Oils; Vegetables and Fruits; Sugar and Gur; Other Food; Clothing and Footwear; Fuel and Light; Other Non Foods.

For rural India as a whole, 68102 households were surveyed in 1993/94. The present study uses the original micro data from this survey. Following the results of our earlier work, [Meenakshi and Ray (1999)], the analysis is carried out separately for each State. The sample

\footnotetext{
${ }^{5}$ See Buhmann, et al (1988), Coulter, et al (1992), Lancaster, et al (1999) for an analogous use of the half sample median or half sample mean of equivalent expenditures as the poverty line in the context of poverty measurement.
} 
size varies from State to State: while the number of observations for the smaller States is less than 500, those for the larger States is over 5000. The demand estimation is carried out only over observations for which the records are complete for each of the above commodity groups. For calculating the head count ratio of poverty, however, the entire sample is used.

Table 1 presents the summary statistics of some of the principal variables of interest in this study. This table also contains the corresponding information on the SC/ST and Female headed households in each State. Household size and cereal share, in particular, vary considerably between States. The rich States of Punjab and Haryana have low average Cereal shares (around .15), while in the poorer States of Bihar and Orissa, the average Cereal share rises to around 0.4. We also observed that the distribution of cereal share across households is skewed in the richer States, for example, Punjab and Haryana with the mode lying between 0.1 and 0.2 , whereas the distribution is more symmetric in Bihar, and the corresponding mode is also much higher, lying between 0.3 and 0.4 . There is thus a priori reason to expect that the behaviourally determined poverty rates (BD) based on a priori specified Cereal shares may well rank States differently from those based on the official poverty line (OPL). The female headed households are smaller in size compared to the others. Both the groups, namely, SC/ST and FHH, generally own considerably less land holdings than the others. In per capita terms, however, the FHH enjoy, in most States, higher aggregate expenditure than the others. However, as we report later, this picture of relative affluence of the FHH changes drastically if we allow size economies of scale and non identical consumption needs between adults and children.

Table 2 reports the sample correlation between the state wise mean values of the major variables. These show some variation in the magnitudes between the SC/ST and FHH groups. The nature and magnitude of association between per capita total expenditure (PCTE) and household size has attracted considerable attention. Table 2 shows that, in contrast to the 
rest of the population, the larger sized FHH do enjoy significantly higher per capita expenditure. The expected positive association, at the aggregate State level, between per capita total expenditure and the size of the household's land holdings is only a weak one as seen from the statistical insignificance of the estimated correlation coefficients.

\section{Results}

Table 3 presents the estimates, for each State, of the economies of household size, $\theta$, and of the adult equivalence scale, $\rho$, under the quadratic and linear specifications [see eqn. (1)]. Since $\theta, \rho$ determine the aggregate expenditure deflator, they need to be commodity invariant. This table also reports the estimate of the quadratic coefficient $\gamma_{c}$ in the Cereals share equation. Estimates of the other demand parameters will be made available on request. The following results emerge from this table.

(i) Regardless of which Engel curve specification one adopts, there is wide variation across States in the estimates of $\theta$ and $\rho$. The present evidence does not, therefore, support the normal practice on Indian data of using the same expenditure deflator in all States to correct for changes in household size and composition in making welfare comparisons across households.

(ii) With the solitary exception of the $\theta$ estimate for Sikkim, the estimates of $\theta$ and $\rho$ are sensible and well determined in nearly all cases. The quadratic coefficient $\left(\gamma_{c}\right)$ of the Cereals equation is significant in most of the States. There is some variation in the estimates of $\theta, \rho$ between the linear and quadratic specifications, though the differences do not seem large enough to justify the increased computations in the latter estimation.

(iii) Almost without exception, the estimates of $\theta$ and $\rho$ are significantly different from unity. In other words, the data finds evidence of significant economies of household size and of non identical consumption needs between adults and children and, thus, rejects the common practice of using per capita expenditure in the poverty calculations. We also observed that, in all cases, the most general demographic specification, ie. with $\theta \neq 1, \rho \neq 1$, leads to a significant likelihood based improvement over that with $\theta \neq 1, \rho=1$ (imposed). In other words, even in the presence of adult/child relativity, the hypothesis of no size economies $(\rho=1)$ is rejected using the likelihood ratio test. This suggests that the recent practice of using

$\mathrm{N}^{\theta}$ as the equivalence scale, with $\mathrm{N}$ denoting the number of household members may not be satisfactory either since the size economies parameter, $\theta$, cannot be relied upon 
to pick up satisfactorily the effect of changes in household composition between adults and children. The household compositional variables need to be explicitly introduced in the equivalence scale specification.

Table 4 provides evidence on the sensitivity of the head count measures of household poverty to the alternative demographic adjustments of OPL, including the conventional per capita treatment implicit in OPL3, and between the 'Cereal Ratio' Method [using eqn. (2)] and the OPL variants. This table also reports, for each State, the index of 'land deprivation' (LD) or landlessness, as defined earlier. The State rankings, corresponding to the various poverty lines and indices, are prese nted in Table 5 with 1 denoting the poorest State and so on. The following conclusions follow.

(i) Comparing the most general and most restricted treatment of household size, namely, OPL1, OPL3, we find that the introduction of economies of household size and non identical consumption needs between adults and children leads to a sharp reduction in the estimate of household poverty. A further comparison between the OPL1 and OPL4 based poverty estimates shows that, in the absence of explicit presence of household compositional variables (ie. $\rho=1$ ), the simple introduction of economies of household size, ie. non unitary $\theta$, is unlikely to yield a satisfactory outcome, since the latter estimates are still completely out of line, indeed highly upward biased, in relation to the former. Table 5 shows, however, that, unlike the poverty estimates, the State poverty rankings are not very sensitive to the alternative variants of OPL. In contrast, the State poverty estimates and the poverty rankings are both highly sensitive to the methodology used in setting the poverty line, ie. they vary sharply between BDPL and OPL. Note, incidentally, that the revision to the poverty estimates between these methods is not always unidirectional. The high sensitivity of the BDPL poverty estimates to the budget share of Cereals used as cut off, coupled with the fact that any cut off adopted has to be ad hoc, constitute a serious limitation of the 'Cereals Ratio' method.

(ii) The estimates of landlessness (LD) generally show a much higher level of deprivation than is implied by the poverty estimates. The rich States of Punjab and Haryana experience a higher level of landlessness in the countryside than several of the poorer States. We should stress, however, that LD conveys only an incomplete picture on poverty, since not all landless households are poor nor are all large landowners above the poverty line.

(iii) The results on the sharp sensitivity of the State poverty rankings to the choice of method in fixing the poverty line (BDPL, OPL) and their robustness to the economies of household size and scale relativities between adults and children (OPL1 - OPL4) 
are confirmed by the Spearman rank correlation estimates and their standard errors presented in Table 6.

Tables 7, 8 present the estimates of household poverty and of landlessness of the SC/ST and FHH groups, respectively, in each State. A comparison of the poverty estimates reported in Tables 4, 7, 8 shows that these groups experience higher poverty than the others. Note that this picture is robust between measures (BDPL, OPL, LD) and between their variants. The SC/ST and FHH register much higher levels of land deprivation than the rest of the population. For example, in the rich agricultural States of Punjab and Haryana, over $90 \%$ of the SC/ST households are landless. Female headed households in Punjab exhibit one of the highest levels of landlessness among all female headed households in rural India. Even in States like Kerala and West Bengal, with an impressive record of land reforms under Communist rule, these minority groups, especially SC/ST households in Kerala, exhibit high levels of landlessness.

Table 8 shows that, in sharp contrast to the other groups, the poverty rates of the FHH generally, though not always, increase with the introduction of size economies and scale relativities between adults and children ie. when we move from OPL3 to OPL1. FHH are generally smaller in household size and older in average age compared to the others and, hence, less able to take advantage of size economies in consumption, and of the lower consumption needs of the child in relation to the adult. This is confirmed visually by Fig. 1 which presents the picture on poverty, using poverty lines OPL1 and OPL3, in six of the larger States in India. In Andhra Pradesh and Madhya Pradesh, for example, the introduction of size economies of consumption and of scale relativities between adults and children makes the FHH, under OPL1, one of the poorest subgroups in these States. It is important to note, however, that in several States (eg. Haryana, Kerala, Orissa), this is not the case, with the introduction of size economies and adult/child relativities there leading to a decrease in the 
poverty rates of female headed households [see Table 8, Fig. 1]. This unde rlines one of the central messages of this study, namely, the lack of robustness of the all India picture obtained by Dreze and Srinivasan (1997) between the constituent States of the Indian Union. Fig. 2, which presents the picture on poverty in the six States by the size of landholdings, confirms that the household poverty rates do fall with an increase in the size of landholdings. It is noticeable, however, that there are some poor households among those with "large land holdings". It will be useful to analyse the characteristics of such households in future research.

\section{Summary and Conclusion}

This paper exploits the rich information from the $50^{\text {th }}$ round of the National Sample Survey of household expenditure in rural India conducted in 1993/94 and recently made available in its original unit record form. We combine the expenditure and demographic information contained in the unit records of nearly 70,000 households to analyse rural poverty in India.

The study initially tests for the presence of significant consumption economies of household size and of non identical consumption needs between adults and children by estimating the corresponding behavioural parameters for each of the constituent States of the Indian Union. Nearly all the States confirm the simultaneous presence of these demographic effects. The results argue against the conventional use of unadjusted household size as the expenditure or income deflator in the poverty calculations. They also suggest that the household size economies parameter cannot be relied upon to satisfactorily pick up household composition effects as well. The head count poverty rates fall, quite sharply in many cases, with the introduction of the State specific consumption economies of household size and of adult/child relativities in the equivalence scale used as the expenditure deflator. A significant 
exception is provided by the experience of the female headed households for whom the poverty rates in several States move in exactly the opposite direction, ie. rise in the presence of size economies, reflecting their inability to take advantage of the demographic adjustments because of their smaller size, and the smaller number of children in these households. It is important to note, however, that this result, also noted by Dreze and Srinivasan (1997), is not true for every State.

In contrast to the poverty estimates, the State poverty rankings are fairly robust between the alternative demographic adjustments to the poverty line based on the alternative values assigned to the parameters in the equivalence scale specification. However, the State poverty rankings change significantly between the alternative methods used to determine the poverty line itself, namely, between the behaviourally determined method using the budget share of Cereals, and the official poverty line based on nutritional requirements. Scheduled caste, scheduled tribe and, in certain States in the presence of size economies and adult/child relativities, female headed households face higher poverty rates than the rest of the rural population.

Rural poverty, especially in the Indian subcontinent, is a complex phenomenon - for an insightful analysis of rural poverty in India, see Galbraith (1979). The causes of rural poverty are many and varied. Clearly, more research needs to be done to identify target groups for directing poverty alleviation strategies, and to determine the strategies that are likely to be effective. The present study, we hope, is a step in that direction. 
Table 1 : Summary Statistics of Ke y Variables ${ }^{\text {a }}$

\begin{tabular}{|c|c|c|c|c|c|c|c|c|c|c|c|c|c|c|}
\hline & \multirow[b]{2}{*}{ State } & Sample & \multicolumn{4}{|c|}{ All Households } & \multicolumn{4}{|c|}{ SC/ST Households } & \multicolumn{4}{|c|}{ Female Headed Households } \\
\hline & & $\begin{array}{c}\text { No. of } \\
\text { House- } \\
\text { holds }\end{array}$ & $\begin{array}{l}\text { Per Capita } \\
\text { Total } \\
\text { Expenditure }\end{array}$ & $\begin{array}{l}\text { House- } \\
\text { hold } \\
\text { Size }\end{array}$ & $\begin{array}{c}\text { Land } \\
\text { Owned } \\
\text { (hectares) }\end{array}$ & $\begin{array}{l}\text { Cereal } \\
\text { Share }\end{array}$ & $\begin{array}{l}\text { Per Capita } \\
\text { Total } \\
\text { Expenditure }\end{array}$ & $\begin{array}{l}\text { House- } \\
\text { hold } \\
\text { Size }\end{array}$ & $\begin{array}{c}\text { Land } \\
\text { Owned } \\
\text { (hectares) }\end{array}$ & $\begin{array}{l}\text { Cereal } \\
\text { Share }\end{array}$ & $\begin{array}{c}\text { Per Capita } \\
\text { Total } \\
\text { Expenditure }\end{array}$ & $\begin{array}{l}\text { House- } \\
\text { hold } \\
\text { Size }\end{array}$ & $\begin{array}{c}\text { Land } \\
\text { Owned } \\
\text { (hectares) }\end{array}$ & $\begin{array}{l}\text { Cereal } \\
\text { Share }\end{array}$ \\
\hline$\overline{1}$ & Andhra Pradesh & 4908 & 308.53 & 4.16 & 0.75 & 0.27 & 258.48 & 4.05 & 0.45 & 0.30 & 299.05 & 2.43 & 0.39 & 0.27 \\
\hline 2 & Arunachal Pradesh & 1065 & 360.35 & 4.59 & 1.86 & 0.32 & 324.15 & 4.83 & 2.14 & 0.33 & 312.55 & 2.57 & 1.32 & 0.32 \\
\hline 3 & Assam & 3199 & 267.70 & 5.09 & 0.73 & 0.35 & 262.75 & 5.06 & 0.88 & 0.36 & 264.47 & 3.94 & 0.36 & 0.30 \\
\hline 4 & Bihar & 6979 & 230.34 & 4.99 & 0.69 & 0.39 & 207.18 & 4.58 & 0.53 & 0.43 & 229.82 & 3.52 & 0.46 & 0.38 \\
\hline 5 & Goa & 146 & 503.87 & 4.29 & 0.37 & 0.16 & 450.14 & 4.14 & 0.12 & 0.15 & 426.01 & 3.38 & 0.27 & 0.16 \\
\hline 6 & Gujarat & 2219 & 326.7 & 5.05 & 1.21 & 0.18 & 287.29 & 4.92 & 0.58 & 0.19 & 333.74 & 3.60 & 0.57 & 0.17 \\
\hline 7 & Haryana & 1040 & 412.77 & 5.55 & 1.41 & 0.15 & 303.83 & 5.46 & 0.51 & 0.18 & 450.65 & 4.23 & 0.99 & 0.14 \\
\hline 8 & Himachal Pradesh & 1875 & 395.56 & 5.01 & 0.81 & 0.21 & 330.02 & 4.93 & 0.58 & 0.24 & 440.34 & 4.01 & 0.67 & 0.20 \\
\hline 9 & Jammu and Kashmir & 819 & 378.26 & 5.65 & 0.97 & 0.23 & 352.14 & 5.71 & 0.63 & 0.26 & 399.52 & 4.79 & 0.75 & 0.23 \\
\hline 10 & Karnataka & 2617 & 288.59 & 5.11 & 1.24 & 0.24 & 242.5 & 5.00 & 0.67 & 0.26 & 281.47 & 3.55 & 0.80 & 0.25 \\
\hline 11 & Kerala & 2555 & 422.91 & 4.56 & 0.29 & 0.20 & 319.55 & 4.27 & 0.10 & 0.23 & 421.99 & 3.99 & 0.29 & 0.20 \\
\hline 12 & Maharashtra & 4440 & 293.99 & 4.73 & 1.34 & 0.20 & 245.86 & 4.59 & 0.79 & 0.21 & 315.45 & 2.86 & 0.84 & 0.20 \\
\hline 13 & Manipur & 1000 & 308.82 & 5.33 & 0.85 & 0.41 & 307.65 & 4.98 & 0.94 & 0.42 & 344.54 & 4.30 & 0.51 & 0.37 \\
\hline 14 & Meghalaya & 1116 & 349.82 & 4.43 & 0.77 & 0.26 & 343.36 & 4.46 & 0.80 & 0.26 & 373.83 & 3.94 & 0.61 & 0.24 \\
\hline 15 & Mizoram & 470 & 414.57 & 5.01 & 1.40 & 0.21 & 414.76 & 5.02 & 1.42 & 0.21 & 456.28 & 3.97 & 1.17 & 0.20 \\
\hline 16 & Madhya Pradesh & 5312 & 260.3 & 5.11 & 1.82 & 0.30 & 223.77 & 4.79 & 1.40 & 0.33 & 265.77 & 2.92 & 1.07 & 0.30 \\
\hline
\end{tabular}


Table 1: (Continued)

\begin{tabular}{|c|c|c|c|c|c|c|c|c|c|c|c|c|c|c|}
\hline & \multirow[b]{2}{*}{ State } & Sample & \multicolumn{4}{|c|}{ All Households } & \multicolumn{4}{|c|}{ SC/ST Households } & \multicolumn{4}{|c|}{ Female Headed Households } \\
\hline & & $\begin{array}{c}\text { No. of } \\
\text { House- } \\
\text { holds }\end{array}$ & $\begin{array}{c}\text { Per Capita } \\
\text { Total } \\
\text { Expenditure }\end{array}$ & $\begin{array}{l}\text { House- } \\
\text { hold } \\
\text { Size }\end{array}$ & $\begin{array}{c}\text { Land } \\
\text { Owned } \\
\text { (hectares) }\end{array}$ & $\begin{array}{c}\text { Cereal } \\
\text { Share }\end{array}$ & $\begin{array}{c}\text { Per Capita } \\
\text { Total } \\
\text { Expenditure }\end{array}$ & $\begin{array}{l}\text { House- } \\
\text { hold } \\
\text { Size }\end{array}$ & $\begin{array}{c}\text { Land } \\
\text { Owned } \\
\text { (hectares) }\end{array}$ & $\begin{array}{l}\text { Cereal } \\
\text { Share }\end{array}$ & $\begin{array}{c}\text { Per Capita } \\
\text { Total } \\
\text { Expenditure }\end{array}$ & $\begin{array}{l}\text { House- } \\
\text { hold } \\
\text { Size }\end{array}$ & $\begin{array}{c}\text { Land } \\
\text { Owned } \\
\text { (hectares) }\end{array}$ & $\begin{array}{l}\text { Cereal } \\
\text { Share }\end{array}$ \\
\hline 17 & Nagaland & 460 & 465.76 & 5.29 & 1.59 & 0.28 & 458.74 & 5.33 & 1.65 & 0.28 & 467.15 & 3.79 & 1.27 & 0.28 \\
\hline 18 & Orissa & 3338 & 234.03 & 4.71 & 0.70 & 0.42 & 205.71 & 4.36 & 0.59 & 0.44 & 248.64 & 2.91 & 0.52 & 0.41 \\
\hline 19 & Punjab & 2046 & 455.85 & 5.19 & 1.25 & 0.12 & 378.74 & 4.98 & 0.37 & 0.14 & 613.74 & 4.04 & 0.77 & 0.12 \\
\hline 20 & Rajasthan & 3096 & 340.3 & 5.23 & 2.60 & 0.20 & 291.41 & 4.99 & 1.57 & 0.22 & 361.10 & 3.51 & 1.83 & 0.20 \\
\hline 21 & Sikkim & 480 & 347.14 & 4.11 & 0.73 & 0.24 & 346.76 & 4.19 & 0.78 & 0.24 & 374.12 & 3.26 & 0.93 & 0.24 \\
\hline 22 & Tamil Nadu & 3901 & 309.22 & 4.04 & 0.39 & 0.29 & 252.6 & 4.03 & 0.16 & 0.31 & 302.87 & 2.69 & 0.23 & 0.29 \\
\hline 23 & Tripura & 1530 & 361.41 & 4.45 & 0.64 & 0.28 & 328.13 & 4.41 & 0.66 & 0.30 & 325.38 & 2.56 & 0.30 & 0.30 \\
\hline 24 & Uttar Pradesh & 9011 & 293.27 & 5.35 & 0.85 & 0.25 & 242.99 & 4.91 & 0.39 & 0.29 & 301.44 & 3.55 & 0.52 & 0.26 \\
\hline 25 & West Bengal & 4480 & 293.06 & 4.99 & 0.39 & 0.38 & 256.04 & 4.81 & 0.32 & 0.41 & 285.88 & 3.32 & 0.27 & 0.37 \\
\hline
\end{tabular}

a The figures denote sample means; the per capita total expenditure figures relate to expenditure over 30 days. 
Table 2: Correlation Between the State Mean Values of the Variables

\begin{tabular}{|c|c|c|c|c|}
\hline \multicolumn{5}{|c|}{ All Households } \\
\hline & $\begin{array}{c}\text { Per Capita } \\
\text { Total } \\
\text { Expenditure }\end{array}$ & $\begin{array}{l}\text { Household } \\
\text { Size }\end{array}$ & Land Owned & $\begin{array}{l}\text { Cereal } \\
\text { Share }\end{array}$ \\
\hline & 1.00 & & & $-0.69^{a}$ \\
\hline Household Size & & 1.00 & $0.45^{\mathrm{a}}$ & -0.04 \\
\hline Land Owned & & & 1.00 & -0.23 \\
\hline Cereal Share & & & & 1.00 \\
\hline \multicolumn{5}{|c|}{ SC/ST Households } \\
\hline Per Capita Total Expenditure & 1.00 & 0.18 & 0.19 & $-0.56^{\mathrm{a}}$ \\
\hline Household Size & & 1.00 & 0.37 & -0.12 \\
\hline Land Owned & & & 1.00 & 0.11 \\
\hline Cereal Share & & & & 1.00 \\
\hline \multicolumn{5}{|c|}{ Female Headed Households } \\
\hline Per Capita Total Expenditure & 1.00 & $0.52^{\mathrm{a}}$ & 0.26 & $-0.73^{\mathrm{a}}$ \\
\hline Household Size & & 1.00 & 0.09 & -0.36 \\
\hline Land Owned & & & 1.00 & -0.24 \\
\hline Cereal Share & & & & 1.00 \\
\hline
\end{tabular}

${ }^{a}$ Statistically significant at 5\% level of significance. 
Table 3: Selected Parameter Estimates ${ }^{\text {a }}$ of Cereals Share Equation

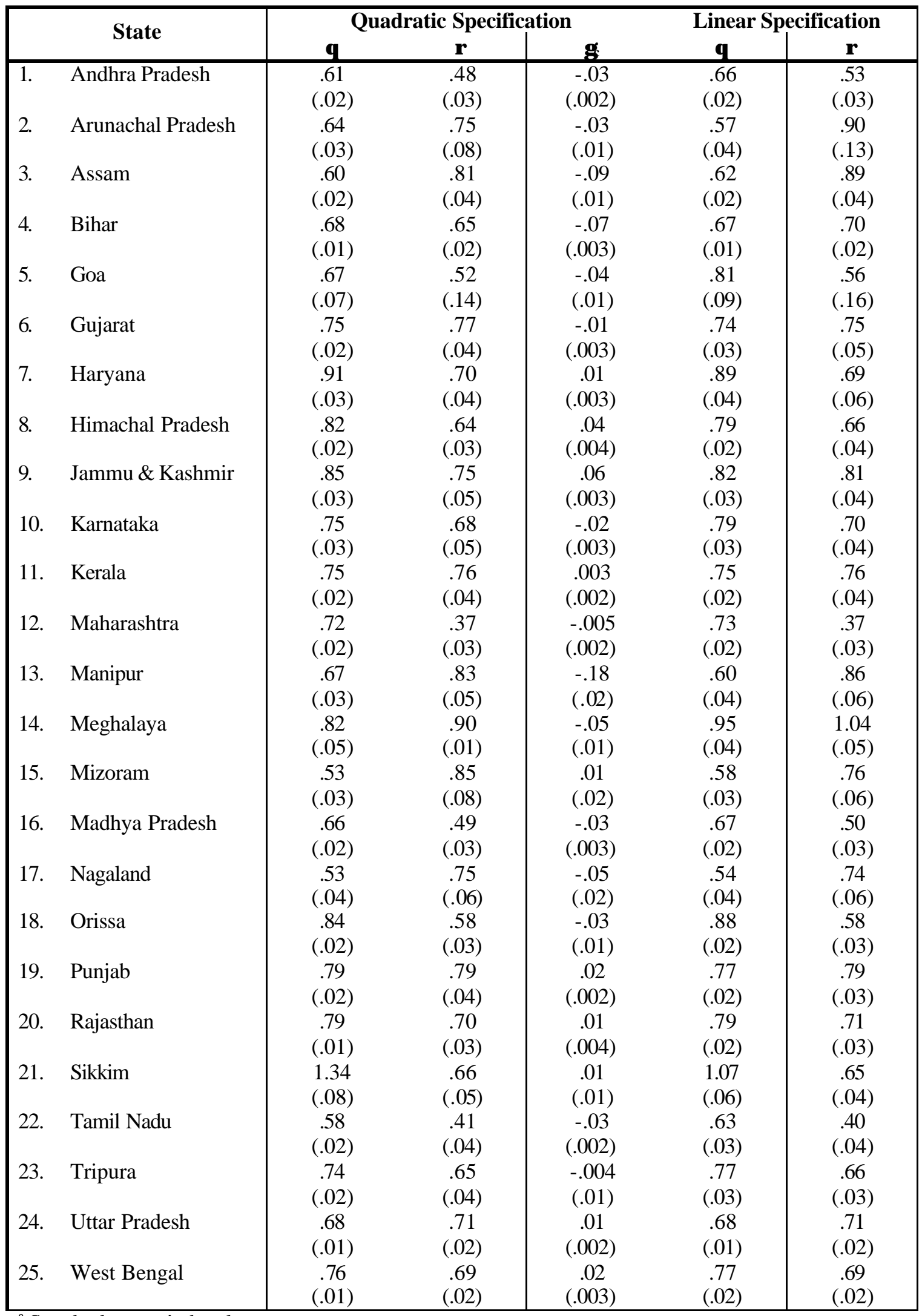

${ }^{\mathrm{a}}$ Standard errors in brackets. 
Table 4: Estimates of Poverty and Land Deprivation (All Households)

\begin{tabular}{|c|c|c|c|c|c|c|c|c|}
\hline & \multirow{3}{*}{ State } & \multicolumn{6}{|c|}{ Head Count Poverty Rate (\% age) } & \multirow{3}{*}{$\begin{array}{c}\text { Land } \\
\text { Deprivation } \\
\text { (\% age) } \\
\text { LD }\end{array}$} \\
\hline & & \multicolumn{2}{|c|}{ Cereal Ratio $^{a}$} & \multicolumn{4}{|c|}{ Official Poverty Line (OPL) ${ }^{\mathbf{b}}$} & \\
\hline & & BD1 & BD2 & OPL1 & OPL2 & OPL3 & OPL4 & \\
\hline 1. & Andhra Pradesh & 2.5 & 20.8 & 13.9 & 9.8 & 23.4 & 27.2 & 53.7 \\
\hline 2. & Arunachal Pradesh & 14.9 & 57.1 & 29.9 & 21.9 & 40.3 & 40.0 & 37.4 \\
\hline 3. & Assam & 70.6 & 93.8 & 43.9 & 40.8 & 49.5 & 53.0 & 43.0 \\
\hline 4. & Bihar & 82.8 & 94.9 & 47.3 & 39.0 & 57.6 & 60.4 & 51.7 \\
\hline 5. & Goa & 0.0 & 0.7 & 5.5 & 4.8 & 8.9 & 7.5 & 56.2 \\
\hline 6. & Gujarat & 0.0 & 0.1 & 17.6 & 13.8 & 23.7 & 25.1 & 51.9 \\
\hline 7. & Haryana & 0.0 & 0.1 & 13.7 & 13.1 & 22.5 & 21.8 & 51.2 \\
\hline 8. & Himachal Pradesh & 0.7 & 5.1 & 15.0 & 13.8 & 26.6 & 25.3 & 40.7 \\
\hline 9. & Jammu \& Kashmir & 1.0 & 8.8 & 9.3 & 7.7 & 13.7 & 15.1 & 36.0 \\
\hline 10. & Karnataka & 0.2 & 1.6 & 19.8 & 18.2 & 28.2 & 29.0 & 46.1 \\
\hline 11. & Kerala & 0.1 & 0.8 & 20.1 & 18.9 & 25.8 & 25.9 & 52.8 \\
\hline 12. & Maharashtra & 0.1 & 0.1 & 24.4 & 23.0 & 42.0 & 44.6 & 48.1 \\
\hline 13. & Manipur & 97.5 & 99.8 & 25.6 & 18.2 & 29.8 & 32.7 & 36.6 \\
\hline 14. & Meghalaya & 0.9 & 5.7 & 22.2 & 20.5 & 26.2 & 25.6 & 33.8 \\
\hline 15. & Mizoram & 17.0 & 61.7 & 8.1 & 3.8 & 8.3 & 10.0 & 23.4 \\
\hline 16. & Madhya Pradesh & 22.3 & 53.2 & 17.4 & 13.6 & 30.5 & 33.3 & 40.5 \\
\hline 17. & Nagaland & 11.1 & 44.6 & 2.0 & 1.5 & 3.5 & 4.1 & 14.3 \\
\hline 18. & Orissa & 69.8 & 83.7 & 34.9 & 30.5 & 47.9 & 50.0 & 45.7 \\
\hline 19. & Punjab & 0.0 & 0.0 & 8.2 & 6.6 & 11.9 & 12.2 & 57.8 \\
\hline 20. & Rajasthan & 0.1 & 1.6 & 12.4 & 9.9 & 20.1 & 20.9 & 46.1 \\
\hline 21. & Sikkim & 0.0 & 0.8 & 25.6 & 20.4 & 29.4 & 33.3 & 41.3 \\
\hline 22. & Tamil Nadu & 5.8 & 31.0 & 22.2 & 19.4 & 33.8 & 37.5 & 58.4 \\
\hline 23. & Tripura & 15.0 & 40.3 & 20.1 & 17.4 & 28.2 & 29.4 & 53.5 \\
\hline 24. & Uttar Pradesh & 12.0 & 32.5 & 26.7 & 19.6 & 33.8 & 36.1 & 43.8 \\
\hline 25. & West Bengal & 65.7 & 80.6 & 31.9 & 29.4 & 43.8 & 46.3 & 49.9 \\
\hline
\end{tabular}

${ }^{\mathrm{a}} \mathrm{BD} 1, \mathrm{BD} 2$ correspond to $\hat{\mathrm{w}}_{\text {cereals }}=0.40,0.35$ respectively.

${ }^{\mathrm{b}}$ OPL1-OPL4 correspond to $\rho, \theta$ (estimated); $\rho$ (estimated), $\theta=1 ; \rho=1, \theta=1 ; \rho=1, \theta$ (estimated), respectively. 
Table 5: State Rankings Based on Poverty and on Land Deprivation

\begin{tabular}{|c|c|c|c|c|c|c|c|c|}
\hline & \multirow{3}{*}{ State } & \multicolumn{6}{|c|}{ Head Count Poverty Rate (\% age) } & \multirow{3}{*}{$\begin{array}{c}\text { Land } \\
\text { Deprivation } \\
\text { (\% age) } \\
\text { LD }\end{array}$} \\
\hline & & \multicolumn{2}{|c|}{ Cereal Ratio $^{a}$} & \multicolumn{4}{|c|}{ Official Poverty Line (OPL) } & \\
\hline & & BD1 & BD2 & OPL1 & OPL2 & OPL3 & OPL4 & \\
\hline 1. & Andhra Pradesh & 13 & 13 & 18 & 20 & 18 & 14 & 4 \\
\hline 2. & Arunachal Pradesh & 9 & 7 & 5 & 6 & 6 & 6 & 20 \\
\hline 3. & Assam & 3 & 3 & 2 & 1 & 2 & 2 & 16 \\
\hline 4. & Bihar & 2 & 2 & 1 & 2 & 1 & 1 & 8 \\
\hline 5. & Goa & 22 & 21 & 24 & 23 & 23 & 24 & 3 \\
\hline 6. & Gujarat & 21 & 24 & 15 & 15 & 17 & 18 & 7 \\
\hline 7. & Haryana & 23 & 23 & 19 & 18 & 19 & 19 & 9 \\
\hline 8. & Himachal Pradesh & 16 & 16 & 17 & 16 & 14 & 17 & 18 \\
\hline 9. & Jammu \& Kashmir & 14 & 14 & 21 & 21 & 21 & 21 & 22 \\
\hline 10. & Karnataka & 17 & 18 & 14 & 13 & 13 & 13 & 12 \\
\hline 11. & Kerala & 19 & 20 & 13 & 11 & 16 & 15 & 6 \\
\hline 12. & Maharashtra & 20 & 22 & 9 & 5 & 5 & 5 & 11 \\
\hline 13. & Manipur & 1 & 1 & 8 & 12 & 10 & 11 & 21 \\
\hline 14. & Meghalaya & 15 & 15 & 10 & 7 & 15 & 16 & 23 \\
\hline 15. & Mizoram & 7 & 6 & 23 & 24 & 24 & 23 & 24 \\
\hline 16. & Madhya Pradesh & 6 & 8 & 16 & 17 & 9 & 10 & 19 \\
\hline 17. & Nagaland & 11 & 9 & 25 & 25 & 25 & 25 & 25 \\
\hline 18. & Orissa & 4 & 4 & 3 & 3 & 3 & 3 & 14 \\
\hline 19. & Punjab & 24 & 25 & 22 & 22 & 22 & 22 & 2 \\
\hline 20. & Rajasthan & 18 & 17 & 20 & 19 & 20 & 20 & 13 \\
\hline 21. & Sikkim & 25 & 19 & 7 & 8 & 11 & 9 & 17 \\
\hline 22. & Tamil Nadu & 12 & 12 & 11 & 10 & 8 & 7 & 1 \\
\hline 23. & Tripura & 8 & 10 & 12 & 14 & 12 & 12 & 5 \\
\hline 24. & Uttar Pradesh & 10 & 11 & 6 & 9 & 7 & 8 & 15 \\
\hline 25. & West Bengal & 5 & 5 & 4 & 4 & 4 & 4 & 10 \\
\hline
\end{tabular}

${ }^{\mathrm{a}} \mathrm{BD} 1, \mathrm{BD} 2$ correspond to $\hat{\mathrm{w}}_{\text {cereals }}=0.40,0.35$ respectively.

${ }^{\mathrm{b}}$ OPL1-OPL4 correspond to $\rho, \theta$ (estimated); $\rho$ (estimated), $\theta=1 ; \rho=1, \theta=1 ; \rho=1, \theta$ (estimated), respectively. 
Table 6: Spearman Rank Correlation ${ }^{a}$

\begin{tabular}{|c|c|c|c|c|c|c|c|}
\hline & BD1 & BD2 & OPL1 & OPL2 & OPL3 & OPL4 & LD \\
\hline BD1 & $\begin{array}{l}1.0 \\
(-)\end{array}$ & $\begin{array}{c}.97 \\
(.05)\end{array}$ & $\begin{array}{l}.50^{\mathrm{c}} \\
(.17)\end{array}$ & $\begin{array}{l}.38^{\mathrm{c}} \\
(.18)\end{array}$ & $\begin{array}{l}.54^{\mathrm{C}} \\
(.17)\end{array}$ & $\begin{array}{l}.53^{\mathrm{c}} \\
(.17)\end{array}$ & $\begin{array}{l}-.34^{\mathrm{c}} \\
(.19)\end{array}$ \\
\hline BD2 & & $\begin{array}{c}1.00 \\
(-)\end{array}$ & $\begin{array}{l}.50^{\mathrm{c}} \\
(.17)\end{array}$ & $\begin{array}{l}.38^{\mathrm{c}} \\
(.19)\end{array}$ & $\begin{array}{l}.51^{\mathrm{c}} \\
(.17)\end{array}$ & $\begin{array}{l}.51^{\mathrm{c}} \\
(.17)\end{array}$ & $\begin{array}{l}-.42^{\mathrm{c}} \\
(.18)\end{array}$ \\
\hline OPL1 & & & $\begin{array}{c}1.00 \\
(-)\end{array}$ & $\begin{array}{c}.97 \\
(.05)\end{array}$ & $\begin{array}{c}.94 \\
(.07)\end{array}$ & $\begin{array}{c}.94 \\
(.07)\end{array}$ & $\begin{array}{l}-.01^{\mathrm{c}} \\
(.20)\end{array}$ \\
\hline OPL2 & & & & $\begin{array}{c}1.00 \\
(-)\end{array}$ & $\begin{array}{c}.93 \\
(.08)\end{array}$ & $\begin{array}{c}.92 \\
(.08)\end{array}$ & $\begin{array}{l}.02^{\mathrm{c}} \\
(.20)\end{array}$ \\
\hline OPL3 & & & & & $\begin{array}{c}1.00 \\
(-)\end{array}$ & $\begin{array}{c}.99 \\
(.03)\end{array}$ & $\begin{array}{l}.05^{\mathrm{c}} \\
(.20)\end{array}$ \\
\hline OPL3 & & & & & & $\begin{array}{c}1.00 \\
(-)\end{array}$ & $\begin{array}{l}.09^{c} \\
(.20)\end{array}$ \\
\hline LD & & & & & & & $\begin{array}{c}1.00 \\
(-)\end{array}$ \\
\hline
\end{tabular}

${ }^{\text {a }}$ Standard errors in brackets.

${ }^{\mathrm{b}}$ Significantly different from unity at 5\% level.

${ }^{\mathrm{c}}$ Significantly different from unity at $1 \%$ level. 
Table 7: Estimates of Poverty and Land Deprivation in SC/ST Households

\begin{tabular}{|c|c|c|c|c|c|c|c|c|}
\hline & \multirow{3}{*}{ State } & \multicolumn{6}{|c|}{ Head Count Poverty Rate (\% age) } & \multirow{3}{*}{$\begin{array}{c}\text { Land } \\
\text { Deprivation } \\
\text { (\% age) } \\
\text { LD }\end{array}$} \\
\hline & & \multicolumn{2}{|c|}{ Cereal Ratio $^{a}$} & \multicolumn{4}{|c|}{ Official Poverty Line (OPL) } & \\
\hline & & BD1 & BD2 & OPL1 & OPL2 & OPL3 & OPL4 & \\
\hline 1. & Andhra Pradesh & 4.7 & 36.1 & 24.6 & 18.1 & 37.2 & 45.4 & 64.7 \\
\hline 2. & Arunachal Pradesh & 16.3 & 57.7 & 31.1 & 23.6 & 41.3 & 41.1 & 31.1 \\
\hline 3. & Assam & 74.7 & 96.6 & 43.3 & 41.4 & 52.1 & 54.6 & 37.5 \\
\hline 4. & Bihar & 93.3 & 98.1 & 65.3 & 53.7 & 71.6 & 78.5 & 69.4 \\
\hline 5. & Goa & 0.0 & 0.0 & 0.0 & 0.0 & 0.0 & 0.0 & 66.7 \\
\hline 6. & Gujarat & 0.0 & 0.0 & 28.3 & 22.5 & 34.2 & 37.5 & 64.7 \\
\hline 7. & Haryana & 0.0 & 0.4 & 26.0 & 23.4 & 40.0 & 40.0 & 91.3 \\
\hline 8. & Himachal Pradesh & 1.7 & 8.8 & 22.5 & 20.4 & 35.7 & 37.0 & 54.0 \\
\hline 9. & Jammu \& Kashmir & 1.7 & 14.5 & 14.5 & 12.0 & 20.1 & 22.6 & 55.6 \\
\hline 10. & Karnataka & 0.3 & 2.6 & 33.2 & 29.8 & 43.3 & 45.9 & 65.2 \\
\hline 11. & Kerala & 0.0 & 0.4 & 34.9 & 32.0 & 39.4 & 42.8 & 79.9 \\
\hline 12. & Maharashtra & 0.2 & 0.2 & 35.7 & 31.9 & 56.0 & 60.9 & 62.8 \\
\hline 13. & Manipur & 98.7 & 100.0 & 34.1 & 25.2 & 38.9 & 43.0 & 18.9 \\
\hline 14. & Meghalaya & 0.9 & 5.8 & 22.2 & 20.7 & 26.4 & 25.6 & 31.7 \\
\hline 15. & Mizoram & 17.2 & 61.5 & 8.2 & 3.9 & 8.4 & 10.1 & 22.8 \\
\hline 16. & Madhya Pradesh & 33.5 & 69.2 & 26.9 & 20.5 & 41.9 & 47.7 & 48.6 \\
\hline 17. & Nagaland & 11.4 & 45.7 & 2.0 & 1.6 & 3.4 & 4.3 & 12.5 \\
\hline 18. & Orissa & 82.6 & 92.4 & 49.7 & 43.6 & 61.8 & 66.1 & 53.0 \\
\hline 19. & Punjab & 0.0 & 0.0 & 17.6 & 14.0 & 24.6 & 25.1 & 95.0 \\
\hline 20. & Rajasthan & 0.4 & 3.4 & 22.4 & 17.3 & 32.7 & 35.7 & 60.0 \\
\hline 21. & Sikkim & 0.0 & 1.6 & 29.5 & 23.3 & 36.4 & 38.8 & 34.1 \\
\hline 22. & Tamil Nadu & 7.7 & 44.8 & 32.2 & 28.1 & 48.6 & 54.3 & 78.5 \\
\hline 23. & Tripura & 21.5 & 51.0 & 27.9 & 24.2 & 36.7 & 39.2 & 53.5 \\
\hline 24. & Uttar Pradesh & 22.7 & 51.2 & 44.2 & 33.1 & 49.7 & 55.9 & 68.4 \\
\hline 25 . & West Bengal & 78.3 & 90.2 & 43.2 & 38.6 & 54.1 & 59.7 & 57.5 \\
\hline
\end{tabular}

${ }^{\mathrm{a}} \mathrm{BD} 1, \mathrm{BD} 2$ correspond to $\hat{\mathrm{w}}_{\text {cereals }}=0.40,0.35$ respectively.

${ }^{\mathrm{b}}$ OPL1-OPL4 correspond to: $\rho, \theta$ (estimated); $\rho$ (estimated), $\theta=1 ; \rho=1, \theta=1 ; \rho=1, \theta$ (estimated); respectively. 
Table 8: Estimates of Poverty and Land Deprivation in Female Headed Households

\begin{tabular}{|c|c|c|c|c|c|c|c|c|}
\hline & \multirow{3}{*}{ State } & \multicolumn{6}{|c|}{ Head Count Poverty Rate (\% age) } & \multirow{3}{*}{$\begin{array}{c}\text { Land } \\
\text { Deprivation } \\
\text { (\% age) } \\
\text { LD }\end{array}$} \\
\hline & & \multicolumn{2}{|c|}{ Cereal Ratio $^{a}$} & \multicolumn{4}{|c|}{ Official Poverty Line (OPL) } & \\
\hline & & BD1 & BD2 & OPL1 & OPL2 & OPL3 & OPL4 & \\
\hline 1. & Andhra Pradesh & 11.3 & 46.6 & 37.1 & 15.9 & 23.1 & 57.3 & 72.0 \\
\hline 2. & Arunachal Pradesh & 32.9 & 76.7 & 54.8 & 16.4 & 30.1 & 64.4 & 34.2 \\
\hline 3. & Assam & 81.0 & 93.5 & 64.9 & 53.6 & 57.7 & 69.0 & 66.1 \\
\hline 4. & Bihar & 87.7 & 96.2 & 61.0 & 37.0 & 58.3 & 75.1 & 57.6 \\
\hline 5. & Goa & 0.0 & 2.9 & 14.7 & 8.8 & 11.8 & 20.6 & 64.7 \\
\hline 6. & Gujarat & 0.0 & 0.0 & 24.2 & 8.1 & 19.4 & 34.7 & 63.7 \\
\hline 7. & Haryana & 0.0 & 0.0 & 14.6 & 11.0 & 20.7 & 24.4 & 46.3 \\
\hline 8. & Himachal Pradesh & 0.8 & 4.9 & 12.8 & 8.2 & 19.1 & 24.0 & 39.8 \\
\hline 9. & Jammu \& Kashmir & 0.0 & 9.5 & 9.5 & 6.7 & 11.4 & 14.3 & 41.0 \\
\hline 10. & Karnataka & 0.6 & 3.1 & 28.9 & 20.4 & 28.3 & 39.9 & 60.1 \\
\hline 11. & Kerala & 0.5 & 2.5 & 24.2 & 20.5 & 27.3 & 30.1 & 50.4 \\
\hline 12. & Maharashtra & 0.0 & 0.2 & 31.6 & 20.7 & 34.6 & 55.3 & 59.4 \\
\hline 13. & Manipur & 95.1 & 100.0 & 32.1 & 12.3 & 21.0 & 37.0 & 51.9 \\
\hline 14. & Meghalaya & 0.5 & 1.9 & 13.9 & 12.0 & 14.4 & 15.8 & 35.4 \\
\hline 15. & Mizoram & 20.0 & 65.0 & 5.0 & 0.0 & 5.0 & 7.5 & 30.0 \\
\hline 16. & Madhya Pradesh & 42.7 & 67.1 & 38.0 & 18.3 & 29.8 & 55.3 & 52.9 \\
\hline 17. & Nagaland & 36.8 & 78.9 & 10.5 & 0.0 & 0.0 & 10.5 & 10.5 \\
\hline 18. & Orissa & 67.1 & 81.7 & 34.9 & 24.1 & 37.6 & 55.6 & 51.2 \\
\hline 19. & Punjab & 0.0 & 0.0 & 8.9 & 5.2 & 8.9 & 11.9 & 70.4 \\
\hline 20. & Rajasthan & 0.4 & 3.4 & 21.1 & 10.8 & 21.1 & 31.9 & 51.7 \\
\hline 21. & Sikkim & 0.0 & 0.0 & 19.2 & 19.2 & 23.1 & 30.8 & 23.1 \\
\hline 22. & Tamil Nadu & 18.1 & 50.8 & 42.7 & 25.6 & 36.8 & 59.8 & 67.0 \\
\hline 23. & Tripura & 42.0 & 63.9 & 47.9 & 30.3 & 37.0 & 58.0 & 62.2 \\
\hline 24. & Uttar Pradesh & 24.0 & 46.6 & 41.6 & 22.6 & 37.7 & 52.5 & 52.8 \\
\hline 25. & West Bengal & 75.0 & 84.8 & 49.1 & 36.3 & 46.0 & 61.9 & 57.9 \\
\hline
\end{tabular}

${ }^{\mathrm{a}} \mathrm{BD} 1, \mathrm{BD} 2$ correspond to $\hat{\mathrm{w}}_{\text {cereals }}=0.40,0.35$ respectively.

${ }^{\mathrm{b}}$ OPL1-OPL4 correspond to: $\rho, \theta$ (estimated); $\rho$ (estimated), $\theta=1 ; \rho=1, \theta=1 ; \rho=1, \theta$ (estimated); respectively. 
Figure 1: Povertv Estimates in Selected States for Aggregate Population and Subgroups (SC/ST, FHH)
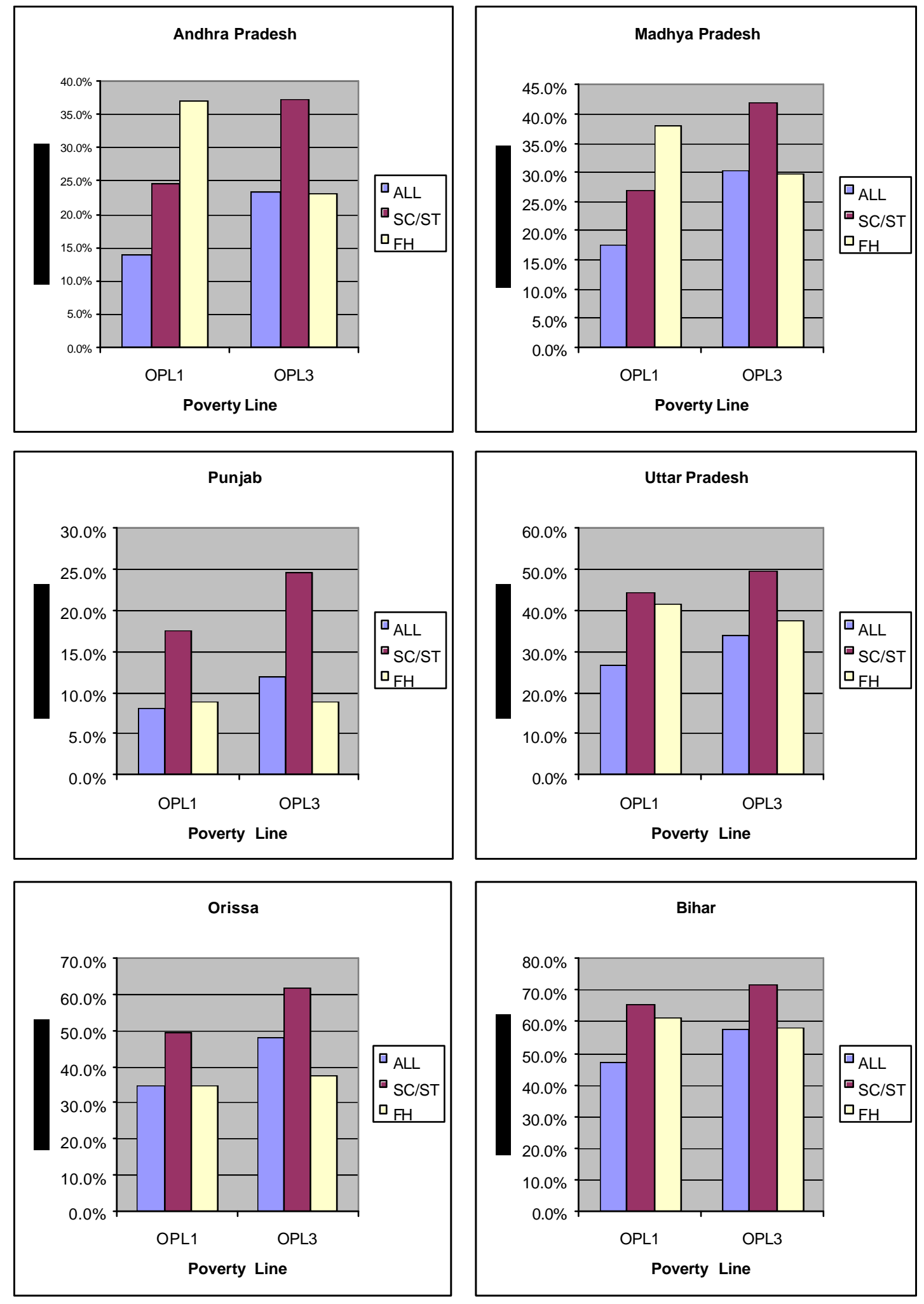
Figure 2: Povertv Estimates in Selected States bv Size of Landholdings ${ }^{\mathrm{a}}$
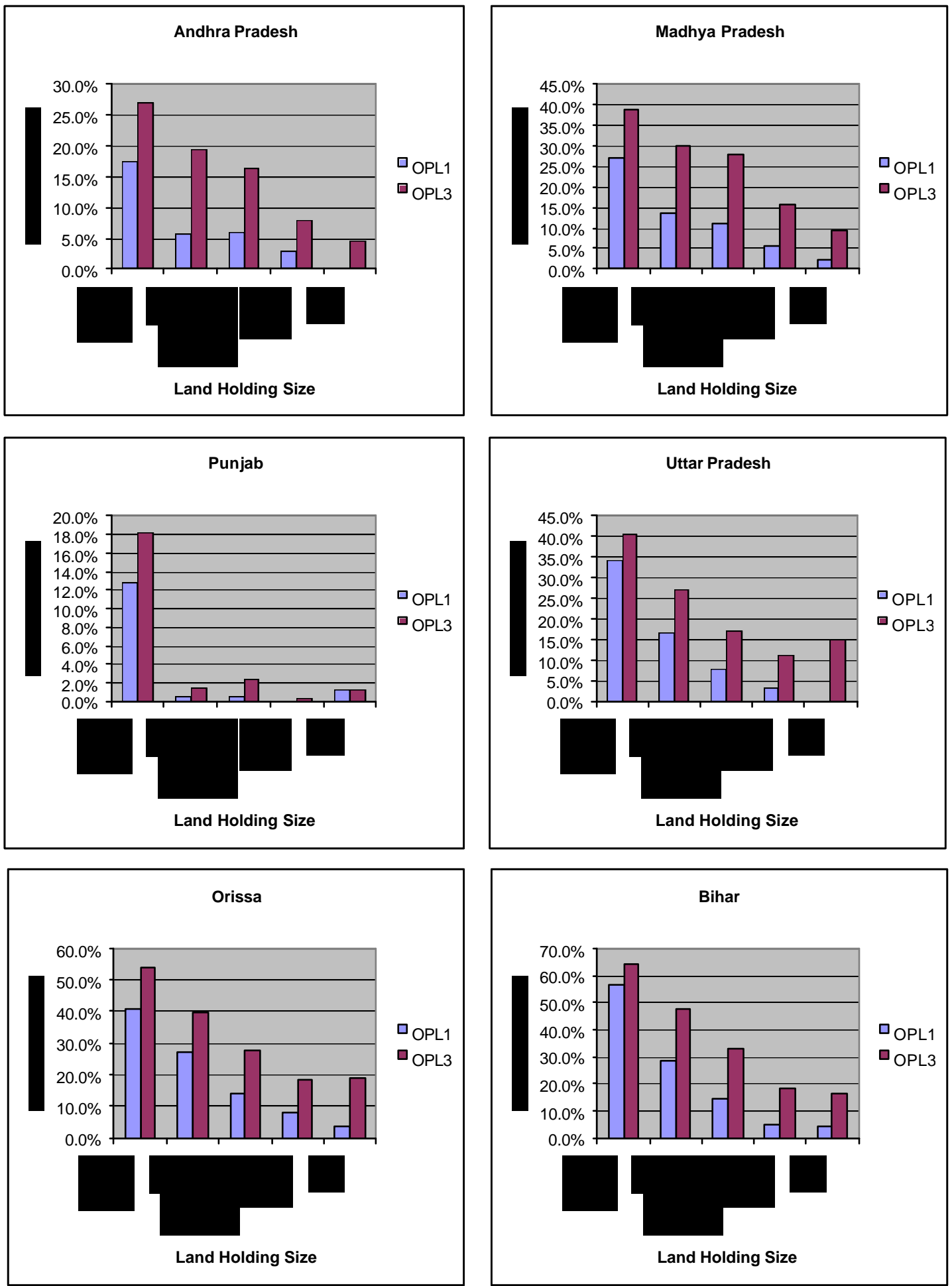

a) The 5 land holding size categories are defined as: $\quad$ 0-1.01 hectares (marginal), 1.01-2 hectares (small), 2-4 hectares (semi medium), 4-10 hectares (medium), and greater than ten hectares (large) 


\section{References:}

Buhmann, B., Rainwater, L., Schmaus, G. and T. Smeeding (1988), "Equivalence Scales, Well-Being, Inequality and Poverty: Sensitivity Across Ten Countries Using the Luxembourg Income Study (LIS) Database", Review of Income and Wealth, 94, 115-142.

Buvinic, M. and G.R. Gupta (1997), "Female-Headed Households and Female-Maintained Families: Are They Worth Targeting to Reduce Poverty in Developing Countries?", Economic Development and Cultural Change, 45(2), 259-280.

Chaudhuri, S. and M. Ravallion (1994), "How Well Do Static Indicators Identify the Chronically Poor?", Journal of Public Economics, 53, 367-394.

Coulter, F.A.E., Cowell, F.A. and S.P. Jenkins (1992), "Equivalence Scale Relativities and the Extent of Inequality and Poverty", Economic Journal, 102, 1067-82.

Datt, G. and M. Ravallion (1998), "Why Have Some Indian States Done Better Than Others at Reducing Rural Poverty?", Economica, 65, 17-38.

Dreze, J. and P.V. Srinivasan (1996), "Poverty in India: Regional Estimates 1987-88", Discussion Paper No. 70, London School of Economics - STICERD, February.

Dreze, J. and P.V. Srinivasan (1997), "Widowhood and Poverty in Rural India: Some Inferences from Household Survey Data", Journal of Development Economics, 54(2), 217-234.

Dubey, A. and S. Gangopadhyay (1998), Counting the Poor: Where Are the Poor in India?, Sarvekshana, Analytical Report Number 1, Department of Statistics, Government of India.

Galbraith, J.K. (1979), The Nature of Mass Poverty, Harvard University Press, Cambridge, Massachusetts.

Lancaster, G., Ray, R. and R. Valenzuela (1999), "A Cross Country Study of Household Poverty and Inequality on Unit Record Household Budget Data", Economic Development and Cultural Change, 48(1), 177-208.

Lanjouw, P. and M. Ravallion (1995), "Poverty and Household Size", Economic Journal, 105, 14151434.

Meenakshi, J.V. and R. Ray (1999), "Regional Differences in India's Food Expenditure Pattern: A Complete Demand Systems Approach", Journal of International Development, 11, 47- 74.

Minhas, B.S., Jain, L.R., Kansal, S.M. and M.R. Saluja (1990), "Rural Cost of Living: 1970-71 to 1983, States and All India", Indian Economic Review, 25(1), 75-104.

Nelson, J.A. (1988), "Household Economies of Scale in Consumption: Theory and Evidence", Econometrica, 56, 1310-1314.

Nolan, B. and C.T. Whelan (1996), Resources Deprivation and Poverty, Clarendon Press, Oxford.

Pollak, R.A. and T.J. Wales (1979), "Welfare Comparisons and Equivalence Scales", American Economic Review, 69(2), 216-221.

Pollak, R.A. and T.J. Wales (1992), Demand System Specification and Estimation, OUP, Oxford.

Rao, V.V. (1981), "Measurement of Deprivation and Poverty Based on the Proportion Spent on Food", World Development, 9(4), 337-353.

Ringen, S. (1991), "Households, Standard of Living, and Inequality", Review of Income and Wealth, $37(1), 1-13$. 